\title{
STOCK MARKET DEVELOPMENT BEYOND THE GFC: THE CASE OF V4 COUNTRIES
}

\author{
- Jana Vychytilova
}

\begin{abstract}
The stock exchanges are widely considered to be pivotal institutions providing the capital for companies and helping them to gain competitive advantage through economies of scale. This paper examines and sheds additional insight into the stock market behaviour of countries of Visegrad Group, namely the Czech Republic, Slovak Republic, Poland and Hungary, beyond the global financial crisis. The study uses data about official stock market indices of the four official stock exchanges in the Visegrad region, between the years 2010-2016. It applies the correlation analysis in attempt to find out whether the indices, namely the BUX Index, PX Index, SAX Index and WIG 20 Index, have similarities in their behaviour, beyond the crisis. The results indicate the V4 stock markets of geographically connected economics exhibit significant similarities in their behaviour, in the post-crisis period. The paper, inter alia, stresses the importance of the stock markets and provides a coherent overview on official V4 stock markets and their official stock market indices.
\end{abstract}

Keywords: stocks, performance, V4 countries, correlation, return

JEL classification: O16, G12; G15.

\section{INTRODUCTION}

The capital market activity is an important part of the financial intermediation processes. Public capital markets as a form of non-bank lending are highly important for companies. Recently, a strong political emphasis has been put also on the SME finance and the concrete solutions on how to improve SMEs' access to capital markets and how the implementation of solutions are of practitioners as well as academic scholars' interest (FESE, 2012). The stock market has traditionally been viewed as an economic activity leading indicator.

The Visegrad Group (also generally referred to as the "Visegrad Four" or "V4") mirrors the efforts of the Central European countries to collaborate in various fields of common interest within the European integration. The Czech Republic, Hungary, Poland and Slovakia have traditionally been sharing cultural and intellectual values and have generally known roots in diverse religious traditions, which they wish to preserve and further strengthen. All the countries of the Visegrad Group aspired to become members of the European Union, perceiving their integration in the European Union as a further step in the process of overcoming artificial dividing lines in Europe through mutual support. In 2004 (1st May), the V4 countries all became members of the European Union and reached this aim. (Visegrad Group, 2018). In the Visegrad region, four official stock exchanges operate, in particular, the Prague Stock Exchange (PSE), the Bratislava Stock Exchange (BSSE), the Budapest Stock Exchange (BÉT) and the Warsaw Stock Exchange (WSE). 
The Prague Stock Exchange (PSE, CEESEG - Prague) is the oldest and largest organizer of the securities market in the Czech Republic. After a 50-year break that was caused by WW II and the Communist regime, it was opened again in 1993. It resumed the activities of the Prague Commodities and Stock Exchange established in 1871. The PSE is a member of the Federation of European Securities Exchanges (FESE), and the U.S. Securities and Exchange Commission (SEC) is granting the PSE the status of "Designated Offshore Securities Market" by including the PSE on its list of stock exchanges safe for investors. Since September 2009, the PSE has been a member of the CEE Stock Exchange Group (Group), which included initially three more Central European stock exchanges: Budapest Stock Exchange (Budapesti Értéktőzsde), Ljubljana Stock Exchange (Ljubljanska borza) and Vienna Stock Exchange (Wiener Börse). In September 2009 when the Group firstly entered international stock exchange markets, the total market capitalization of the group represented nearly one half of the total market capitalization and nearly two thirds of all trading share transactions in Central and Eastern Europe. Thus the CEESEG Group was the largest stock exchange player in the region. However, the holding company CEESEG Group has currently only two subsidiaries - Prague and Vienna stock exchanges. Towards the end of 2010, the PSE had the market capitalization of 31922.18 million EUR, 27 listed companies with YTD 15258.2 millions EUR turnover of shares, 0.2 million EUR turnover of bonds and 6.7 million EUR turnover of derivatives (44 securitised derivatives listed at EoM). Compared to the end of 2016, the PSE has the market capitalization of 22 194.72 million EUR, 25 listed companies with YTD 6213.1 millions EUR turnover of shares, 148.4 million EUR turnover of bonds (115 bonds listed at EoM), 4.7 million EUR turnover of derivatives (71 securitised derivatives listed at EoM), 2.3 million EUR turnover of UCITS (35 UCITS listed at EoM). Among five most traded shares at the PSE (based on percentage of electronic order book turnover) as of the year-end 2016 belong CEZ, MONETA MONEY BANK, KOMERCNI BANKA, ERSTE GROUP BANK and O2 C.R. (FESE, 2010; FESE, 2016; PSE, 2010; PSE, 2016).

The Bratislava Stock Exchange (BSSE) was established on 15 March 1991 as a regulated market for securities, with a Decree of the Ministry of Finance of the Slovak Republic. The Bratislava Stock Exchange, a legal entity registered in the Companies Register of the County Court Bratislava, started its commercial activity on 6 April 1993. As well as in other stock exchanges worldwide, the BSSE offers an electronic trading system and is based on a membership principle. Currently, the BSSE provides its services on the basis of a licence issued by the National Bank of Slovakia. As of the year-end 2010, a total of 240 issues of securities (bonds and shares- 6 issues were placed on the main listed market, 11 stocks on the parallel listed market and 96 issues on the regulated free market) were placed on the markets of the BSSE, in particular, 31 issues on the main listed market, 75 issues on the parallel listed market and 134 issues on the regulated free market. In 2010, investors continued to prefer investment in debt securities $(96.61 \%$ of the total financial volume) over stocks. On the last trading day of the year 2010, transactions on the BSSE could be concluded in 108 share issues (out of 90 issuers). (BSSE, 2010) Compared to the year-end 2016, the market capitalisation of equity securities traded on the BSSE's markets increased to 4340 million EUR and there were 270 issues of securities (68 share issues, 202 bond issues) placed on the markets of the BSSE (out of which, 24 issues were placed on the main listed market, 25 issues on the parallel listed market and 221 issues were on the regulated free market). 
However, over the last several years, the Slovak regulated market has been at the lowest levels within the EU from the viewpoint of liquidity, depth, volumes and market capitalisation, and has ranked among extremely illiquid markets. (BSSE, 2016).

The Budapest Stock Exchange (BÉT) was re-established in 1 March 1990 with the Securities Act and introduced the electronic trading. The BÉT resumed the activities of the Hungarian Stock Exchange established in 1864. The BÉT was a member of the CEE Stock Exchange Group (CEESEG) between January 2010 and 20 November 2015, until Hungarian National Bank (NBH) concluded a sales contract with the Austrian CEESEG AG and Österreichische Kontrollbank AG (the former owners of the BSE) and obtained the controlling ownership in the BÉT. The newly published BÉT's strategy report for 2016-2020 indicates the BÉT plan to implement announced stock exchange development programme that can result in capital fundraising, increasing BÉT's role in the Hungarian corporate finance, making it a more effective alternative to so prevalent credits provided by banks. The BÉT is one of the members of the Federation of European Securities Exchanges (FESE). Towards the end of 2010, BÉT had market capitalization of 20624.40 million EUR, 52 listed companies with YTD 19925.4 million EUR turnover of shares, 804.7 million EUR turnover of bonds, 205.1 million EUR turnover of derivatives (48 securitised derivatives listed at EoM), 2.4 million EUR turnover of ETFs (1 ETFs listed at EoM), 35 million EUR (87 UCITS listed at EoM). Compared to the end of 2016, the BÉT has market capitalization of 21270.44 million EUR, 42 listed companies with YTD 7347.5 million EUR of turnover of shares, 4.7 million EUR turnover of bonds (101 bonds listed at EoM), 298.2 million EUR turnover of derivatives (121 securitised derivatives listed at EoM), 1.3 million EUR turnover of ETFs (1 ETFs listed at EoM), 39.6 million EUR turnover of UCITs (145 UCITs listed at EoM). Among five most traded shares at BÉT (based on percentage of electronic order book turnover) as of the year-end 2016 belong OTP, MOL, RICHTER, MTELEKOM and FHB. (BSE, 2010; BSE, 2016; FESE, 2010; FESE, 2016).

The Warsaw Stock Exchange (WSE, GPW) is the central institution of the Polish capital market. The WSE was reopened in 1991 (Ebrill et al., 1994). The WSE is one of the members of the Federation of European Securities Exchanges (FESE) and a partner stock exchange of Sustainable Stock Exchange Initiative (SSE Initiative). As of the year-end 2010, WSE reaches 142272.23 million EUR market capitalization, the value of YTD 52260.0 million EUR of turnover of shares (585 listed companies), 319.6 million EUR turnover of bonds, 70.9 million EUR turnover of derivatives (148 listed securitised derivatives at EoM), 17.7 million EUR turnover of ETFs (1 ETFs listed at EoM), 26.5 million EUR turnover of UCITs (58 UCITs listed at EoM). Compared to the end of 2016, market capitalization 130988.46 million EUR, 893 listed companies of 2016 (487 equities were traded on WSE), YTD 43664.6 million EUR of turnover of shares, 539 million EUR turnover of bonds (566 bonds listed at EoM), 204.1 million EUR turnover of derivatives ( 784 securitised derivatives listed at EoM), 42.7 million EUR turnover of ETFs (3 ETFs listed at EoM), 12.6 million EUR turnover of UCITs (37 UCITs listed at EoM). Among five most traded shares at WSE (based on percentage of electronic order book turnover) as of the year-end 2016 belong PEKAO, KGHM, PZU, PKNORLEN and PKOPB. (FESE, 2010; FESE, 2016; WSE, 2010; WSE, 2016)

The research, theoretical or empirical, related to the linkages among stock markets in the Visegrad region is relatively scarce. The main aim of this paper is to investigate whether the pairs of official stock markets of the V4 countries correlate, beyond the GFC. The assessment of behav- 
iour of the V4 stock markets exhibit, in particular, whether the indices, namely the BUX Index, PX Index, SAX Index and WIG 20 Index have similarities in their behaviour beyond the crisis and how these markets move in relation to each other, can be of practitioners' using correlation in portfolio management as well as academic scholar's interest. The study is not oriented to interdependence and contagion.

The paper is further organized as follows. Chapter 2 critically analyses the literature focused on the importance of capital markets and on the comparative behaviour of equity indices. Chapter 3 explains data and methodology that is adopted, including a brief description of official V4 stock market indices. The main empirical results are reported and discussed in Chapter 4. The limitation and future research direction is mentioned in Chapter 4, as well. Conclusion and concluding references are included in the final section.

\section{THEORETICAL BACKGROUND}

\subsection{The importance of stock markets and assessment of their behaviour}

The importance of capital markets has been widely recognized. The stock market has traditionally been viewed as a leading indicator of economic activity, or so called predictor of economy (Harvey, 1989).

Most studies, historically dealing with the financial sector's role and financial intermediation with economic growth have concreted models that usually include three financial markets money, demand and supply, indirect securities, and primary securities - as part of a general equilibrium model (Fatemi \& Salvatore, 2012).

Building blocks around capital market theory are still somehow centred around market efficiency and asset pricing and its important principals lading to partial equilibrium models based on risk and returns (see Fatemi \& Salvatore, 2012; Lintner, 1965; Markowitz, 1959; Mossin, 1966; Ross, 1976; Sharpe, 1964).

Alfaro et. al. (2003) discuss the important role financial markets play in allowing spill-overs and linkages associated with FDI. In particular, the investigators focus on local financial markets' role by using the cross-country analysis. They show, inter alia, the well-developed financial markets significantly gain from foreign direct investment.

Several other studies are oriented to investigating the importance of stock markets with connection to FDI (for example, Alfaro et al, 2004, 2010; Baker, Foley \& Wurgler, 2004; Bekaert et al, 2005; Hermes \& Lensink, 2003; Levine et al, 2000; Levine \& Zervos, 1998; and more).

In general, the literature on the linkages between financial market development, economic growth and FDI seeks to find whether foreign direct investment is only efficient at boosting growth when certain conditions are met, in particular, a fairly developed financial sector; and to provide evidence that liberalized financial markets and well-functioning financial one can help spur growth. (Soumaré \& Tchana, 2015)

Public capital markets, in particular stock markets, are widely considered as an important part of the financial intermediation processes as a form of non-bank lending for companies. Moreover, 
nowadays, the stress is placed also on SMEs' access to capital funding through stock exchanges. (FESE, 2012).

Assessment of behaviour of equity indices is a widely debated issue and is attracting increasing attention (Roll, 1992). A lot of studies is oriented to measuring co-movements between stock markets (for example, Bonfiglioli \& Favero, 2005; Forse \& Rigobon, 2002; and many more).

Forse \& Rigobon (2002) highlight the difference between interdependence, i.e. a high level of co-movement, and contagion. They, inter alia, point out that heteroscedasticity biases tests for contagion based on correlation coefficients are conditional on market volatility.

\section{RESEARCH OBJECTIVE AND METHODOLOGY}

In order to fulfil the previously stated main aim, I set the basic hypothesis that the V4 official stock markets are correlated, beyond the GFC:

H1. The Czech stock (PX) and the Hungarian stock (BUX) markets are positively correlated during the analysed period;

H2: The Czech stock (PX) and the Polish stock (WIG) markets are positively correlated during the analysed period;

H3: The Czech stock (PX) and the Slovakian stock (SAX) markets are positively correlated during the analysed period;

H4: The Hungarian stock (BUX) and the Polish stock (WIG) markets are positively correlated during the analysed period;

H5: The Hungarian stock (BUX) and the Slovakian stock (SAX) markets are positively correlated during the analysed period;

H6: The Polish stock (WIG) and the Slovakian stock (SAX) markets are positively correlated during the analysed period;

The use of the correlation coefficient is essential for the analysis of multiple markets.

\section{Data and methodology}

I collected weekly adjusted closing prices (dividend yields and splits are not considered in calculation) of four stock indices of geographically connected economics, in particular the BUX Index (Hungary), the PX Index (Czechia), the SAX Index (Slovakia) and the WIX 20 Index (Poland) from January 01, 2010 to January 13, 2017 (last available data). The year 2010 as a post-crisis year, was selected based mainly on the finding regarding the capital market in 2010 carrying all the accompanying phenomena of the post-crisis period, identified in the PSE Annual report (PSE, 2010), and stock markets benefited from low interest rates, characterised as revitalisation (BSSE, 2010). Similarly, according to the BSSE Annual Report (BSSE, 2010), the world stock benefited from low interest rates in 2010 and this year is characterised as revitalisation and the most dynamic among the countries of the European Union. The time series were obtained from the Yahoo Finance site and from Bloomberg online databases. The collected time series are firstly denominated to EUR with using appropriate denominator in case of PX Index, BUX Index and 
WIG Index (SAX is already reported by BSSE on the basis of closing prices in EUR of its component), to allow the country comparison. The autocorrelation has not been proven in the data collection. Secondly, relative weekly returns and $\log$ relative weekly returns are calculated by

$r_{t}^{i}{ }_{t-1}=\frac{P_{i}(t)-P_{i}(t-1)}{P_{i}(t-1)}$

where $P$ is the market index weekly closing price adjusted for dividends and splits.

Figure 1 illustrates the development of four official V4 stock market indices, namely the PX Index, BUX Index, SAX Index and WIG 20, between the years 2010 and 2016 (all indices are denominated in EUR terms).

\section{PX}

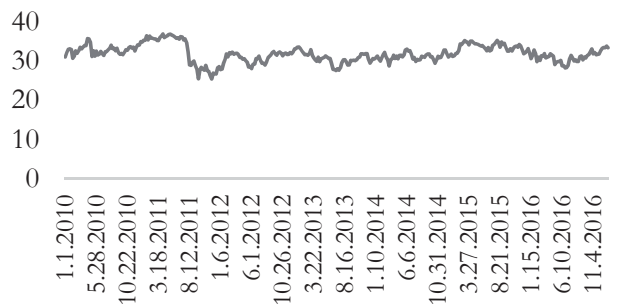

WIG

20000

15000

10000

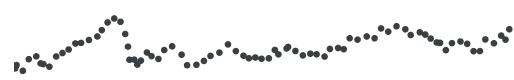

5000

0

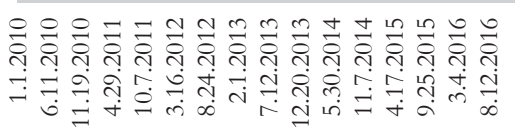

\section{BUX}

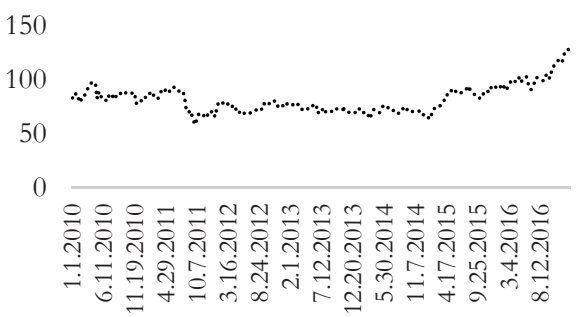

SAX

400

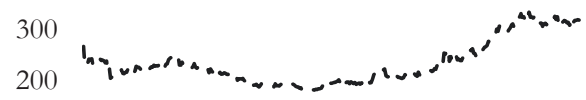

100

0

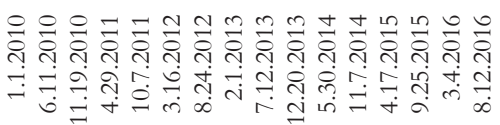

Fig. 1 - Overall V4 Stock indices development beyond GFC (2010-2016, in points denom. to EUR). Source: Own

\section{calculation}

The BUX index was launched on 02 January 1991 with a base value of 1000, being the official index of firms publicly traded on the BÉT (blue chip shares). The BUX index is a free floating, capitalization-weighted total return index, taking account of dividends calculated in real time based on the actual market prices of a basket of shares. The stock index illustrates an average price changing of the shares with the biggest market value and turnover in the equity section. The BUX index is reported by BÉT in points and is calculated continuously. The BUX index is revised twice a year. Historically, the BUX index reached an all-time high of 41516.41 in January 
of 2018 and a record low of 717.75 in May of 1993. The data for a comparative and intermarket study are also available from the BÉT database of historical values.

The PX index (PX, a registered trademark) was launched on 05 April 1994 with a base value of CZK 1000, being an official price index of the PSE, and tracks performance of the 13 top largest companies in the Czech Republic. It is a free float weighted price index made up of the most liquid stocks and it is calculated in real time. The PX index is reported by PSE in points and its daily value is estimated and disclosed on the basis of closing prices in CZK of its components. The index PX does not include dividends and is revised quarterly. Historically, PSE's all-time high is 1936.10 from October of 2007 and its record low is 316 from October of 1998. The data for a comparative study are also available from the PSE database of historical values.

The SAX is an official capital-weighted stock index of the BSSE. It is reported by the BSSE in points and its daily value is estimated and disclosed on the basis of closing prices in EUR of its components. The initial index value of 100 points refers to September 14, 1993. The index includes dividend payments and revenues connected with changes of share capital amount. Since July 1, 200,1 it has been based on closing prices of its components. A regular revision of the base is completed two times every year. Historically, the SAX' all-time high is 507.98 from March of 2005 and a record low 70.19 from March of 2000. The data for a comparative study are also available from the BSSE database of historical values.

The WIG 20 index (WIG20) was launched on 16 April 1994 with a base value of 1000, being the major stock market index the Warsaw Stock Exchange General (WSE, GPW), and tracks performance of the 20 biggest publicly traded companies on the WSE Main list. It is a free float weighted price index, and is continuously reported by WSE in points. The index WIG20 does not include dividends and is adjusted quarterly and revised annually. The WIG20 index may not include more than 5 firms from a single exchange sector. Historically, WIG's all-time high is 67529.39 from January of 2018 and a record low 36549.47 from September of 2011. The data for a comparative study are also available from the WSE database of historical values.

\section{Methods of assessing normality}

Testing for distributional assumptions and for normality in particular is another part of my statistical research. I apply two main approaches of assessing normality, i.e. graphically and numerically. To assess the normality of data, both Q-Q plots and the Shapiro-Wilk test are used, respectively, as a prerequisite for the correlation analysis and parametric testing.

In my research, I tested if the data come from a normal distribution, the Roysten's extension of Shapiro and Wilk- S-W test for normality to large samples, available when $2 \leq \mathrm{n} \leq 2000$ (Shapiro, Wilk \& Chen, 1968; Royston, 1982) to compute the Shapiro-Wilks statistic and its P-Value. The small P-value of the S-W test indicates that the data do not come from a normal distribution. In case the smallest P-value amongst the tests performed is less than 0.05 , the idea that resistivity comes from a normal distribution with $95 \%$ confidence can be rejected. 


\section{Correlation analysis}

The main aim of the paper is to assess the linkages between V4 stock markets, i.e. to investigate whether the correlation between any two stock indices of V4 existed. The research is limited to the correlation analysis and is not oriented to causation.

To find the correlation between two stock indices, in particular whether variables are positively or inversely related, the Spearman's rank correlation coefficient is used for not normally distributed returns of stock indices, while for normally distributed returns of stock indices, the Pearson's correlation coefficients are estimated.

\section{RESULTS AND DISCUSSION}

\section{Normality tests}

Firstly, I test the calculated adjusted weekly returns (dividends and splits are not taken into consideration) for normality, graphically by creating histograms and Q-Q plots, and by Shapiro-Wilk test (S-W test) set upon examining the quantiles of the fitted normal distribution to the quantiles of the data (see Tab.1).

Tab. 1 - The Shapiro-Wilk test. Source: Own processing

\begin{tabular}{|l|l|l|l|l|}
\hline Fitted Distribution Normal & Mean & $\begin{array}{l}\text { Standard } \\
\text { deviation }\end{array}$ & $\begin{array}{l}\text { Shapiro-Wilk } \\
\text { W Statistic }\end{array}$ & P-Value \\
\hline BUX & 0.164522 & 2.85192 & 0.967378 & 0.000041 \\
\hline PX & 0.0512366 & 2.49986 & 0.982767 & 0.350542 \\
\hline SAX & 0.0735466 & 2.2351 & 0.937217 & 0.0 \\
\hline WIG & 0.134744 & 2.54619 & 0.974206 & 0.0075781 \\
\hline
\end{tabular}

Depending on comparing the quantiles of the fitted normal distribution to the quantiles of the data by S-W test (see Tab.1), we cannot reject the idea that PX comes from a normal distribution with $95 \%$ confidence. Since the smallest P-value amongst the tests performed is less than 0.05 , we can reject the idea that BUX, WIG and SAX come from a normal distribution with 95\% confidence (for the visual assessment of how well the normal distribution fits by frequency histograms, see Fig. 3 in Appendix A).

\section{Correlation analysis}

Based on the results of the assessment of how closely the normal distribution fits by visual methods and S-W tests, I apply a non-parametric test that are wherefore less sensitive to outliers to measure the degree of association between two stock market indices in order to investigate whether there is a statistically significant linkage between them and to describe the linkage.

Table 2 shows Spearman rank correlations among each pair of V4 official stock market indices. These correlation coefficients range between -1 and +1 and measure the strength of the association between the variables. The second number in each location of Table 2 is a P-value that tests whether the statistical significance of the estimated correlations is prevalent. P-values below 
0.05 highlight statistically significant non-zero correlations at the $95.0 \%$ confidence level.

Tab. 2 - Are V4 stock market indices correlated? Source: Own processing

\begin{tabular}{|c|c|c|c|c|c|c|c|}
\hline $\begin{array}{l}\text { Spearman } \\
\text { Rank Cor- } \\
\text { relations }\end{array}$ & 2010 & 2011 & 2012 & 2013 & 2014 & 2015 & 2016 \\
\hline \multirow{2}{*}{$\begin{array}{l}\text { PX-BUX } \\
\text { (H1) }\end{array}$} & 0.6212 & 0.6025 & 0.5384 & 0.3888 & 0.4560 & 0.4126 & 0.6667 \\
\hline & 0.0000 & 0.0000 & 0.0001 & 0.0055 & 0.0011 & 0.0035 & 0.0000 \\
\hline \multirow{2}{*}{$\begin{array}{l}\text { PX-WIG } \\
(\mathrm{H} 2)\end{array}$} & 0.6963 & 0.5350 & 0.4733 & 0.4971 & 0.5269 & 0.4431 & 0.4580 \\
\hline & 0.0000 & 0.0001 & 0.0007 & 0.0004 & 0.0002 & 0.0017 & 0.0010 \\
\hline \multirow{2}{*}{$\begin{array}{l}\text { PX-SAX } \\
(\mathrm{H} 3)\end{array}$} & -0.0103 & 0.1673 & -0.1280 & -0.1158 & 0.2254 & 0.1269 & 0.3727 \\
\hline & 0.9412 & 0.2323 & 0.3607 & 0.4084 & 0.1075 & 0.3696 & 0.0072 \\
\hline \multirow{2}{*}{$\begin{array}{l}\text { BUX-WIG } \\
(\mathrm{H} 4)\end{array}$} & 0.5291 & 0.5203 & 0.4475 & 0.1657 & 0.3751 & 0.3233 & 0.4853 \\
\hline & 0.0002 & 0.0002 & 0.0014 & 0.2366 & 0.0074 & 0.0223 & 0.0005 \\
\hline \multirow{2}{*}{$\begin{array}{l}\text { BUX-SAX } \\
(\mathrm{H} 5)\end{array}$} & 0.1999 & 0.1141 & -0.1071 & -0.0491 & 0.1514 & -0.1288 & 0.3758 \\
\hline & 0.1533 & 0.4153 & 0.4442 & 0.7259 & 0.2797 & 0.3625 & 0.0067 \\
\hline \multirow{2}{*}{$\begin{array}{l}\text { WIG-SAX } \\
(\mathrm{H} 6)\end{array}$} & 0.1544 & 0.1308 & 0.1192 & 0.0276 & 0.1322 & 0.1567 & 0.3741 \\
\hline & 0.2700 & 0.3503 & 0.3947 & 0.8439 & 0.3449 & 0.2677 & 0.0070 \\
\hline
\end{tabular}

Spearman rank correlation coefficient

P-Value

All pairs of V4 stock market indices without having SAX in the pair have P-values below 0.05 , highlighting statistically significant non-zero correlations at the $95.0 \%$ confidence level. In all cases having SAX index in the pair, however, P-values above 0.05 are detected statistically not significant (hypotheses H3, H5 and H6 not accepted). This can be potentially explained by the lowest levels within the EU from the viewpoint of liquidity, depth, volumes and market capitalisation and ranking among extremely illiquid markets over the last several years of the Slovak regulated market (BSSE, 2016). The only exception year is detected the year 2016, when a statistically significant positive linkage is identified among all official V4 stock market indices. In other cases, I investigated statistically significant relationship, in particular a positive correlation between PX Index and BUX Index (H1 accepted), between PX Index and WIG 20 Index (H2 accepted), and between BUX Index and WIG 20 Index (H4 accepted, except the year 2013).

In addition, Table 3 shows computed Spearman coefficients with P-values testing the statistical significance of the computed correlations for the overall post-crisis period, so far (2010-2016). Figure 3 (see Appendix B) shows the comprehensive intermarket plot of V4 official stock market indices $(2010=$ base year $)$ and illustrates the behaviour of their computed weekly returns (dividend and splits skipped). According to the assessment of the overall post-crisis period, the positive statistically significant linkages were detected (P-values below 0.05) among all V4 official stock market indices. 
Tab. 3 - Correlations of weekly percentage yields in the post-crisis period $(2010-2016)$. Source: Own processing

\begin{tabular}{|l|l|l|l|l|}
\hline & PX & BUX & WIG & SAX \\
\hline \multirow{2}{*}{ PX } & & 0.6175 & 0.5969 & 0.1495 \\
\cline { 2 - 5 } & & 0.0000 & 0.0000 & 0.0041 \\
\hline \multirow{2}{*}{ BUX } & 0.6175 & & 0.5393 & 0.1254 \\
\cline { 2 - 5 } & 0.0000 & & 0.0000 & 0.0162 \\
\hline \multirow{2}{*}{ WIG } & 0.5969 & 0.5393 & & 0.1543 \\
\cline { 2 - 5 } & 0.0000 & 0.0000 & & 0.0030 \\
\hline \multirow{2}{*}{ SAX } & 0.1495 & 0.1254 & 0.1543 & \\
\cline { 2 - 5 } & 0.0041 & 0.0162 & 0.0030 & \\
\hline
\end{tabular}

Spearman rank correlation coefficient

P-Value

\section{Discussion and limitations of the study and a future research proposal}

I identified several significant similarities in the behaviour of the official V4 stock market indices of geographically connected economics, beyond the GFC period. The enhancing macroeconomic condition has positively affected firms with recently dropping insolvencies, enhancing labour markets with unemployment rates achieving the least levels, most notably in the Czech Republic with four per cent, rising wages and a low inflation, along with improving consumer sentiment and household consumption as the main driving force behind the economic expansion, having constructive outcomes on some sectors in the CEE region. For example, automotive and transport firms dominate the region. (Emerging Europe, 2017). As expected, in the last year of the assessed period, the relative performance of the official V4 stock market indices show a potential to outperform the previous relative returns consistently with the wealth effect theory, in particular, the BÉT's and WSE's official stock market indices (see Fig. 3 in Appendix B). However, the Slovak stock market does not copy the rest V4 stock market development, as was initially indicated in BSSE (2010).

As previously announced, the theoretical and empirical research related to linkages among stock markets of V4 region is relatively scarce. The future research can extend this paper and be oriented on comparing it with the view of the other authors.

The study is limited to measuring whether two stock market indices are significantly related to one another, i.e. in finding out the correlation between two indices. The study does not attempt to examine the causation, i.e. whether the change in one index is causing the change in another, nor deals with dynamic correlations. This can be part of the future research. Similarly, the investigation of the relationships between V4 stock market indices and economic growth, in order to examine whether the indices are leading indicators of economic activity and if stock markets can predict the economy consistent with theory of the traditional valuation model of stock prices, can extend the study. 


\section{CONCLUSION}

The paper discusses Czech, Hungarian, Polish and Slovakian stock markets of geographically connected economics, and sheds some more light whether the V4 official stock market indices have similarities in their behaviour, beyond the global financial crisis (GFC). To find out whether or not the official V4 stock indices probably move in the same direction, beyond the crisis, the correlation coefficients were computed. The assessment of the normality distribution of time series was considered by using the Roysten's extension of Shapiro and Wilk-W, as well as graphical assessment by Q-Q plots and histograms. Annually, the statistically significant positive correlations were detected in almost all pairs of V4 stock market indices, with exception of SAX index. For the overall post-crisis period (2010-2016), the positive statistically significant linkages were detected among all V4 official stock market indices, indicating the similar stock market behaviour of geographically connected economics. The limitations of the study as well as suggestions for the future research were mentioned, in order to explore the area into a comprehensive work.

\section{References}

1. Alfaro, L., Chanda, A., Kalemli-Ozcan, S. \& Sayek, S. (2004). FDI and economic growth: the role of local financial markets. Journal of International Economics, 64 (1), 89-112. https:// doi.org/10.1016/S0022-1996(03)00081-3.

2. Alfaro, L., Chanda, A., Kalemli-Ozcan, S. \& Sayek, S. (2004. FDI and economic growth: The role of local financial markets. Journal of International Economics, 64 (1), 89-112.

3. Baker, M., Foley, F.C. \& Wurgler, J. (2004). The stock market and investment: evidence from FDI flows. NBER, Working Paper 10559 (Online). Retrieved from: http://www.nber. org/papers/w10559.pdf. DOI: 10.3386/w10559.

4. Bekaert, G., Harvey, C. R. \& Lundblad, C. (2005). Does financial liberalization spur growth? Journal of Financial Economics, 77 (1), 3-55.

5. Bonfiglioli, A. \& Favero, C. A. (2005). Explaining co-movements between stock markets: the case of US and Germany. Journal of International Money and Finance, 24 (1), 1299-1316. https://doi.org/10.1016/j.jimonfin.2005.08.016.

6. Bratislava Stock Exchange (BSSE). (2010). Annual Report 2010. Retrieved from http:// http://www.bsse.sk.

7. Bratislava Stock Exchange (BSSE). (2016). Annual Report 2016. Retrieved from http:// http://www.bsse.sk.

8. Budapest Stock Exchange (BSE). (2016). Strategic report 2016. Retrieved from: https:// www.bse.hu/pfile/file?path=/site/Angol/Documents/About_Us/BET-Strategic-Report2016.

9. Ebrill, L. P., Chopra, A., Christofides, Ch., Mylonas, P., Otker, I. \& Schwartz, G. (1994). Poland: The Path to a Market Economy. Washington: International Monetary Fund.

10. Emerging Europe. (2017). Automotive and transport companies dominate the CEE region. (Online). Retrieved from: http://emerging-europe.com/regions/czech-republic/ automotive-and-transport-companies-dominate-the-cee-region/. 
11. Fatemi, K. \& Salvatore, D. (2012). Foreign Exchange Issues, Capital Markets and International Banking in the 1990s. Oxon: Routledge.

12. Federation of European Securities Exchanges (FESE). (2010). Factsheet December 2010. (Online). Retrieved from: http://www.fese.eu/statistics-market-research.

13. Federation of European Securities Exchanges (FESE). (2012). SME access to capital markets funding. (Online). Retrieved from: http://www.fese.eu/images/documents/ positionpapers/2012/FESE\%20SME_final.docx.pdf.

14. Federation of European Securities Exchanges (FESE). (2016). Factsheet December 2016. (Online). Retrieved from: http://www.fese.eu/statistics-market-research.

15. Forbes, K. J. \& Rigobon, R. (2002). No contagion, only interdependence: measuring stock market comovements. Journal of Finance, 57(5), 2223-2261. https://doi.org/10.1111/00221082.00494 .

16. Harvey, C. (1989). Forecasts of economic growth from bond and stock markets. Financial Analyst Journal, 45(5): 38-45. https://doi.org/10.2469/faj.v45.n5.38.

17. Hermes, N., \& Lensink, R. (2003). Foreign direct investment, financial development and economic growth. Journal of Development Studies, 40 (1), 142-63.

18. Levine, R., \& Zervos, S. (1998). Stock markets, banks, and economic growth. American Economic Review, 88 (3), 537-58.

19. Levine, R., Loayza, N. \& Beck, T. (2000). Financial intermediation and growth: causality and causes. Journal of Monetary Economics, 46 (1): 31-77.

20. Lintner, J. (1965). The valuation of risk assets and the selection of risky investments in stock portfolios and capital budgets. Review of Economics and Statistics, 47(1), 13-37.

21. Markowitz, H. (1959). Portfolio Selection. The Journal of Finance, 7(1), 77-91.

22. Mosin, J. (1966). Equilibrium in a capital asset market. Econometrica, 34 (1), 768-783.

23. Prague Stock Exchange (PSE). (2010). 2010 annual report of the CEE Stock Exchange Group and its capital markets 2010/2011. Retrieved from http://ftp.pse.cz/Info.bas/Cz/ vz10-cz-PSE.pdf.

24. Prague Stock Exchange (PSE). (2016). Consolidated annual report 2016. Retrieved from https://www.pse.cz/uploads/u/pse/Vyrocni_zpravy/ar16-en-PSE.pdf.

25. Roll, R. (1992). Industrial Structure and the Comparative Behavior of International Stock Market Indices. The Journal of Finance, 47(1), 3-41, https://doi.org/10.2307/2329089.

26. Ross, S. (1976). The arbitrage theory of capital asset pricing. Journal of Economic Theory, 13 (1), $341-360$.

27. Royston, J. P. (1982). An extension of Shapiro and Wilk-W test for normality to large samples. Journal of the Royal Statistical society Series C, 31 (2). 115-124. https://doi. org/10.2307/2347973.

28. Shapiro, S., Wilk, M., \& Chen, H. (1968). A Comparative Study of Various Tests for Normality. Journal of the American Statistical Association, 63(324), 1343-1372. 
29. Sharpe, W. (1964). Capital asset prices: a theory of market equilibrium under conditions of risk. Journal of Finance, 19 (1), 763-781.

30. Soumaré, I. \& Tchana, F.T. (2015). Causality between FDI and financial market development: evidence from emerging markets. The World Bank Economic Review, 29(1): 205-216). https://doi.org/10.1093/wber/lhv015.

31. Visegrad Group. (2018). About the Visegrad Group. (Online). Retrieved from: http://www. visegradgroup.eu/about.

32. Warsaw Stock Exchange (WSE). (2016). WSE Statistic Bulletin. Retrieved from https:// www.gpw.pl/pub/GPW/statystyki/statystyki_roczne/2016_GPW.pdf.

\section{Contact information}

Ing. Jana Vychytilova, Ph.D.

Tomas Bata University in Zlin, Czech Republic

Faculty of Management and Economics

Department of Finance and Accounting

E-mail:janka.vychytilova@gmail.com

ORCID: 0000-0003-0204-187X 
Appendix A

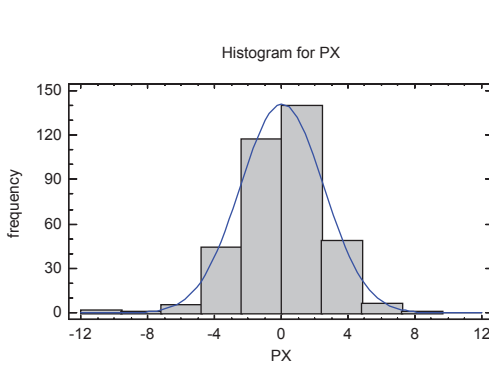

PX
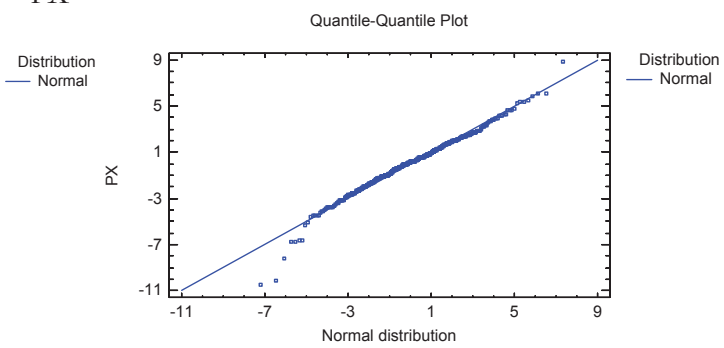

BUX
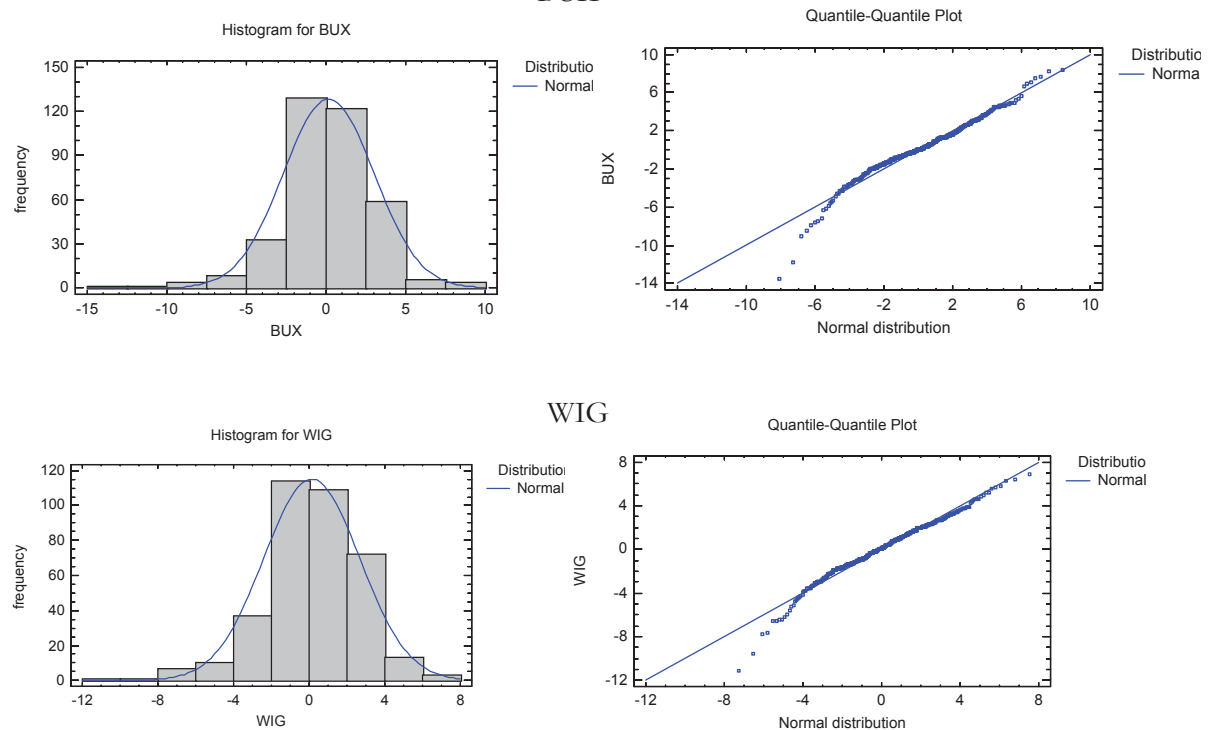

WIG
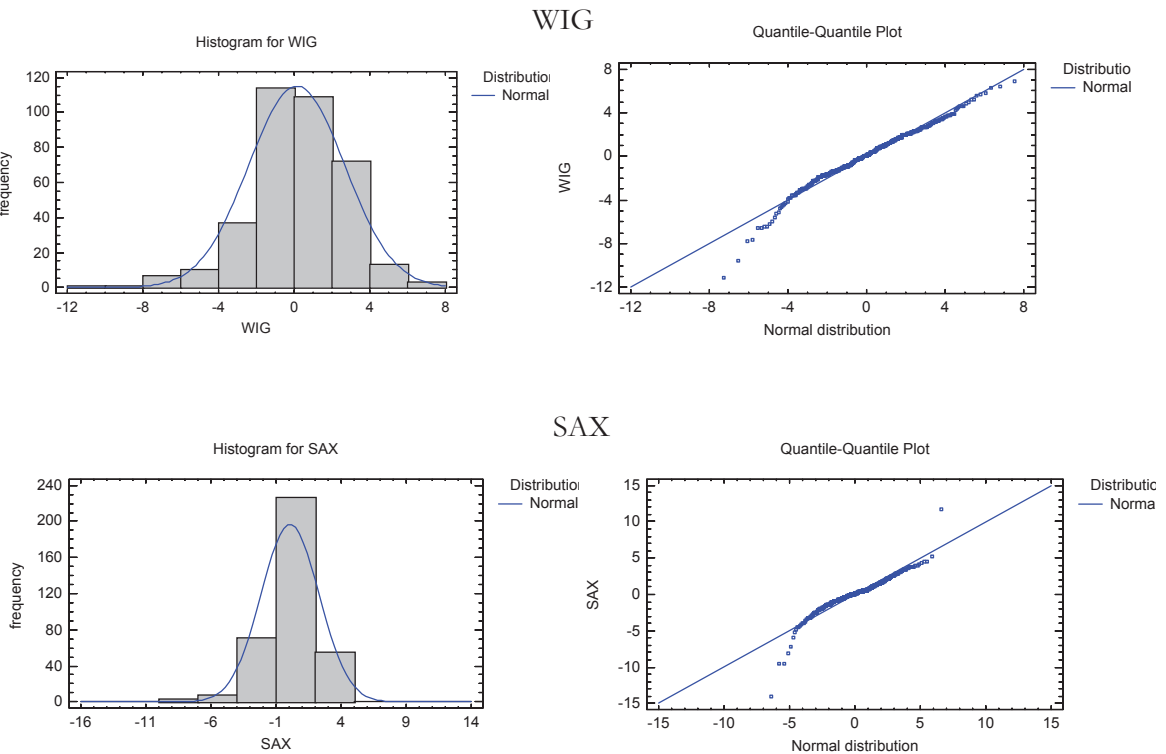

Fig. 2 - Visual assessments of fitting a normal distribution to the V4 stock market indices by creating histograms and Q-Qplots. Source: Own calculation 


\section{Appendix B}

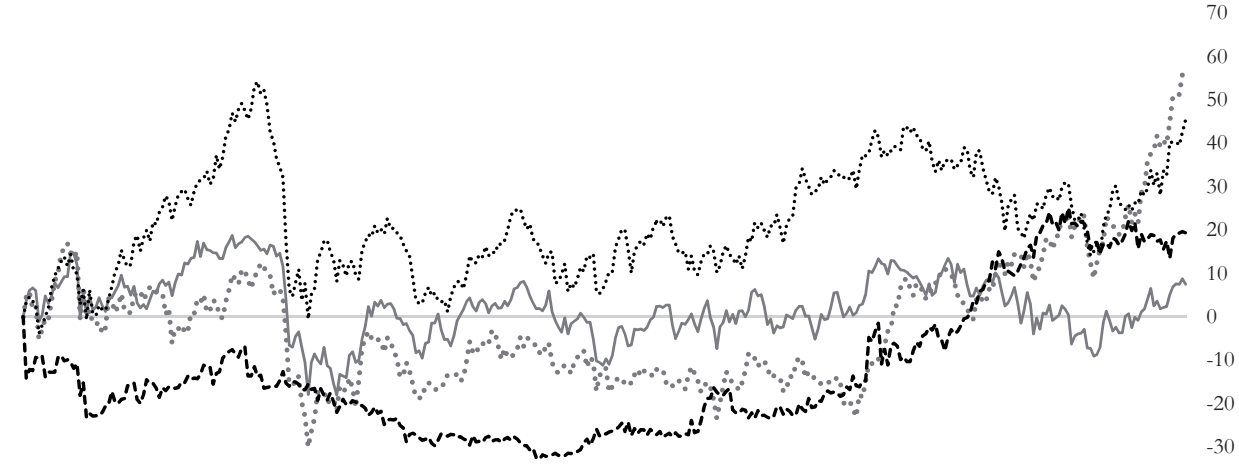

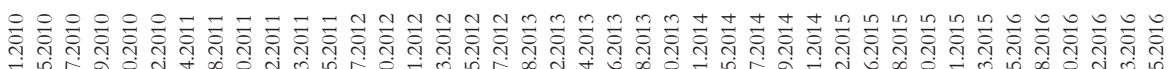

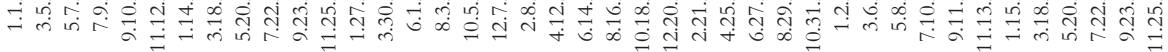

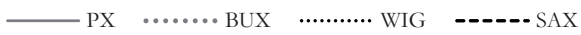

Fig. 3 - Intermarket analysis of V4 official stock market indices beyond GFC (2010-2016, 2010=0). Source: Own calculation 